\title{
An Evaluation on Comprehensive Indonesian-English Dictionary by A. M. Stevens and A. Ed. Schmidgall-Tellings
}

\author{
da Silva, A.M. \\ Department of Applied English Linguistics, Atma Jaya Catholic University, Jakarta, INDONESIA \\ email: anna.silva@atmajaya.ac.id
}

\begin{abstract}
Almost all learners of English as an additional language need a bilingual dictionary. By and large, the dictionary is used to find out meanings of words, though today's modern dictionaries serve more than that particular function. In Indonesia, there have been several widely-known and used bilingual dictionaries aimed for different profiles of target users like learners or practitioners. This article evaluated the latest edition of the Comprehensive Indonesian English Dictionary by Stevens and Schmidgall-Tellings. The purpose of the brief analysis is to give some contribution on the revision of the dictionary's future edition in particular and other Indonesian-English dictionaries in general. It was found that besides the many advantages the dictionary provides to its readers, there have been several aspects that need revisions.
\end{abstract}

Keywords: Bilingual dictionary; evaluation; translator.

\section{INTRODUCTION}

Dictionaries have existed since hundreds of years ago. Dictionaries have been revised and renewed to ensure that the practical needs of readers are fulfilled (Fontenelle, 2008, p. 1). Revision of a dictionary is a must since language is flexible and dynamic (Atkins \& Rundell, 2008, p. 47). Words can be obsolete and are no longer used; they may be simplified and new words may be created in accordance to the language speakers' needs. In that regard, a dictionary has no longer been viewed as the authoritative source from which users will find how to use words; hence the prescriptive function of a dictionary. Nowadays, in line with the advancement of electronic corpora, a dictionary presents real examples of words in written or spoken discourse; hence dictionary as descriptive texts (Atkins \& Rundell, 2008, p. 2).

Therefore, quest to a good dictionary may have no end. Nevertheless, there are some criteria of one. First of all, a dictionary should be able to fulfill the needs of the users (Atkins \& Rundell, 2008, pp. 18, 25-44). Dictionary users are the main element in the process of dictionary making. Profile users include three aspects:

1. Who they are:

a. their ages (e.g. children, adults)

b. their professions (e.g. students, teachers, translators, doctors, etc.)
2. What they need the dictionary for:

a. general purposes (e.g. searching for word definition, finding out word spelling and pronunciation)

b. specific purposes (e.g. learning a foreign language, learning specific terms, translating texts)

3. In which language level they are in:

a. their language proficiency (of the language used in the dictionary)

b. their knowledge on dictionary conventions (e.g. abbreviations, word pronunciation, and grammatical information used in the dictionary)

Simply said, it is the users who will likely decide whether a dictionary they use is good or not. If the user is an adult EFL learner who wants to check meanings of words in a monolingual English dictionary, for instance, he or she will find a monolingual English dictionary useful when the dictionary provides the word meaning in different contexts. He or she can get a complete information on the whole meaning (polysemous) and how they have been used by English native speakers in both formal and informal styles. But if the user is a translator, for example, he or she will find a bilingual dictionary beneficial when it provides not only equivalence of general words, but also specific terms, including abbreviations in the target language and colloquial use of the words in question. 
Second, a good dictionary is reliable in both the subjective and objective evidence (Atkins \& Rundell, 2008, pp. 45-96). Subjective evidence indicates that the dictionary presents an opportunity for its users to make a link between the words and their definitions with their schemata. The connection may be hardly made when users have no background knowledge on the words. Thus, the dictionary functions as a knowledge provider of the word in question. Yet, the connection may be easily created if the users have some previous knowledge about the words they are looking for. In that regard, the dictionary completes the former information the users have possessed. Objective evidence suggests that the dictionary focuses on its descriptive instead of prescriptive role. To put it another way, users will find practical entries and examples, i.e. those that are used in everyday spoken and written contexts, e.g. in daily chats, newspaper articles, novels, and web texts.

Third, a good dictionary should go beyond and responsive to the needs of the users. For instance, a dictionary for an EFL learner should not assume that their users need the dictionary for receptive skills only, but also for productive skills. Academic writing tools should be provided, as has been done by Oxford Advanced Learners Dictionary $8^{\text {th }}$ edition. Furthermore, it should be available on line and is easily used by the users. Finally, it should carry out a periodical revisions so that it is in line with the current and practical use of language.

Based on the users' profile, dictionaries can be categorized into several types according to the following points: (1) language, (2) content, (3) size, (4) medium, (5) organization, (6) skills, and (7) purpose (Atkins \& Rundell, 2008, pp. 24-25). The first category suggests whether a dictionary is a monolingual or bilingual. If it is a bilingual dictionary, it can be unidirectional, e.g. an English-Indonesian dictionary in which English is the source and Indonesian the target language, or bidirectional, e.g. an English-Indonesian and Indonesian-English dictionary in which there are two source languages English and Indonesian, and two target languages Indonesian and English. The second category denotes the subject matter of a dictionary, namely general and specific elements of language (e.g. phrases, collocations, idioms) and specific terminologies (e.g. in health, law, biology). The third category signifies whether a dictionary is of a pocket, concise or collegiate size. The fourth category refers to print, electronic or online version of a dictionary. The fifth category implies the way a dictionary is organized, either from word to meaning, or from word to meaning to other semantically connected word. The sixth category indicates the users' language skills according to their age and linguistic background. The last category suggests two motives of using a dictionary to decode or to encode words. The former is related to the language receptive skills; it means that a dictionary is used to grasp the word definition or translate words from the target into the source language, while the latter is connected to the productive skills, i.e. to employ the words in contexts appropriately, to translate words from a source to a target language, and to teach language.

The categorization above may provide a brief guideline to draw some differences between a dictionary for language learners (English non-native speakers), and for translators. The first factor is the language of the two dictionaries. A dictionary for language learners can be either monolingual, as exemplified by the Longman Language Activator or the Oxford Wordfinder (Atkins \& Rundell, 2008, p. 26), or bilingual, e.g. Kamus Inggris Indonesia edisi yang diperbarui (English-Indonesian Dictionary updated edition, henceforth KIngI) written by Echols and Shadily, published by Gramedia Pustaka Utama. Yet, a dictionary for translators is generally bilingual, e.g. Comprehensive Indonesian-English Dictionary (henceforth CIED), which was written by Alan M. Stevens and the late A. Ed. Schimdgall-Tellings, and published in 1981. It does not mean, however, that translators only need one bilingual dictionary in doing their translation work. They may need other dictionaries as well, e.g. monolingual dictionaries in both the target and source languages, a dictionary of specific fields, e.g. a dictionary of finance, medical or sports and perhaps an encyclopedia, too. The second aspect is the dictionary content or coverage. A dictionary for language learners commonly contains general language in accordance to their age and language background. KIngI, for instance, consists of general language needed by students of Indonesian junior to senior high school levels. CIED, on the other hand, presents both general and specific language such as cultural words, various acronyms and initialism, colloquial expressions, and particular terminologies of different fields, which may be needed for translators. Finally, a dictionary for language learners is used for decoding, as they need the dictionary to comprehend the word meaning or to translate texts from the target to their source language. On the other hand, a dictionary for translators is used for encoding text because they need to find out how to use the words in the target language accurately and to translate texts in the source to the target language. 
This paper is a review of CIED's latest edition. Despite of its great help to translators, the dictionary has its flaws, which, in case of CIED, may not always be easily spotted. Actually, all dictionaries have their own weaknesses. Therefore, good dictionaries ideally would manage to have their revised editions published periodically. Hopefully, the review, which due to some limitations cannot cover the entire aspects of a dictionary and discuss as many examples as possible, would contribute to the revision of the later edition of the dictionary.

\section{GENERAL DESCRIPTION OF THE DICTIONARY}

The very first edition of CIED, a unidirectional dictionary, was published in 1981. The writers, Alan M. Stevens, is a professor of linguistics at Queens College, City University of New York, and the late A. Ed. Schimdgall-Tellings, was a freelance translator. CIED revised edition was published in 2004 , and launched in Indonesia in August 4, 2005 at the library of the Ministry of Education, South Jakarta. In the preface of the 2004 edition, it was stated that the two authors have done research and written books on Indonesian language. However, none of the authors are native speakers of Indonesian, unlike the CollinsRobert English-French Dictionary (henceforth CREFD) whose authors are both native speakers of English (B. T. Sue Atkins) and French (A. Duval), one important fact that probably has made CREFD a reliable reference for its users until it issued its fifth edition then (Atkins B. T., 2008, pp. 247, 249). I attended the launch of CIED in 2005. Hearing about the review and looking at the content of CIED displayed, I was sure to buy the dictionary as I predicted it would provide me a great help in some translation work I had.

Six years afterwards, i.e. in the year 2010, the second edition (or the third edition, to be more precise) was published. This edition has encompassed all the revisions, corrections and additions have from the second and third printing of the previous editions that came not only from the authors and publisher, but also from the users (Stevens \& Schmidgall-Tellings, 2010, p. ix). Indeed, CIED's first and second editions have evidently assisted me in translating some texts occasionally for eight years then. In my opinion, CIED is the best Indonesian-English dictionary for several reasons. First of all, it may be due to the dictionary's ability to assist me translating texts from Indonesian to English. The dictionary consists of a wide range of technical terms in so many fields, from economics to engineering to medical areas, which are commonly needed by translators. Referring to the categories of a dictionary above, CIED's main target users are likely translators, not English learners (Gouws, 2007, pp. 56, 59), especially when it is mentioned that the first edition included some suggestions from Bahtera mailing list for translators and interpreters (Stevens \& Schmidgall-Tellings, 2010, p. xi). Finally, the authors' twenty-year research and documentation of the Indonesian language and culture resulted in real-world utterances in the examples, hence the descriptive evidence (McEnery $\&$ Wilson, 2001, pp. 5, 106-107, 144-145). However, the profile of target users was not explicitly mentioned (vide Table 1). Thus, CIED was created for the purpose of text production (Atkins \& Rundell, 2008, p. 25; Nielsen \& Mourier, 2007, p. 131).

\section{THE MERITS OF CIED}

CIED claims to be more superior than other dictionaries due to a number of factors. Firstly, compared to the other dictionaries like Kamus Indonesia Inggris Trualfa edisi ke-1 (IndonesianEnglish Dictionary $1^{\text {st }}$ edition, henceforth KIIT) by Krause, published in 2002, and the popular Kamus Indonesia Inggris edisi ke 3 (Indonesian English Dictionary $3^{\text {rd }}$ edition henceforth KII) written by Echols and Shadirly, published in 1989 by Gramedia Pustaka Utama, CIED is the biggest in size $(25 \mathrm{x} 19 \mathrm{x}$ $5 \mathrm{~cm}$ ). It belongs to the standard or collegiate edition. It also has much more pages, 1,103 pages and entries of around 80,000 lemmata (vide Table 1). It was available in print. CIED authors claimed to have included standard and non-standard Indonesian words originated from local, slang, teenagers', and foreign languages. The local languages include Javanese, Jakarta, Balinese, Batak, Banjarmasin, Indonesia Bagian Timur, Irian Jaya, Kawi, Madurese, Medan, Minahasa, Nusa Tenggara Barat, Nusa Tenggara Timur, Sunda, Palembang, and Papua. Indonesian language is also highly influenced by foreign languages, especially Arabic Indonesia has the biggest Moslem population in the world; Dutch, who colonialized the country for over than three centuries, and English, through the various dimensions of the relationship between the country and the English speaking countries particularly the US and UK. Other influential foreign languages includes Chinese, German, Greek, Latin, Portuguese and Sanskrit (Sneddon, 2003, pp. 160-177, 180-185). The influence of other languages into Indonesian was well illustrated by CIED.

In addition, CIED clearly listed its primary and secondary sources. The primary sources included newspapers, magazines, books, personal documents, government documents, ministerial decrees, business 
Table 1. Comparison of CIED, KIIT, and KII

\begin{tabular}{|c|c|c|c|c|c|}
\hline Dictionaries & $\begin{array}{c}\text { Year of } \\
\text { publication }\end{array}$ & Size & $\begin{array}{l}\text { No. of } \\
\text { entries }\end{array}$ & $\begin{array}{l}\text { No. of } \\
\text { pages }\end{array}$ & Target readers \\
\hline CIED 2 ed. & 2010 & $25 \times 19 \times 5 \mathrm{~cm}$ & $\begin{array}{l} \pm 80,000- \\
90,000\end{array}$ & 1103 & NA \\
\hline KIIT 1 ed. & 2002 & $\begin{array}{l}23,5 \times 15,5 \times 3,5 \\
\mathrm{~cm}\end{array}$ & $\begin{array}{l}40,000- \\
50,000\end{array}$ & 830 & $\begin{array}{l}\text { Non-fluent English } \\
\text { speakers, and non-native } \\
\text { speakers of English }\end{array}$ \\
\hline KII $3^{\text {rd }}$ ed. & 1989 & $23 \times 15 \times 2.7 \mathrm{~cm}$ & $\begin{array}{l}\text { Less than } \\
31,000\end{array}$ & 618 & $\begin{array}{l}\text { Indonesian learners of } \\
\text { English } \\
\text { General readers wishing } \\
\text { to read contemporary } \\
\text { Indonesian materials }\end{array}$ \\
\hline
\end{tabular}

documents, tape-recorded conversations, street signs, graffiti, restaurant menus, testimony in Immigration court, at civil \& criminal trials and taken at depositions in the United States, and internet sources. The secondary sources comprise various subjectspecific dictionaries from language to other fields such as Islam, Math, Law, sports, telecommunication, engineering, and birds (Stevens \& Schmidgall-Tellings, 2010, pp. xviii-xix). The other two dictionaries did not mention their sources as complete and detailed as CIED did.

Next, the dictionary provides thorough acronyms and initialisms that are available and used frequently in Indonesian contexts. It is a common practice to use one of the following lexical items: asosiasi, badan, ikatan, lembaga, organisasi, paguyuban, perkumpulan, and pusat for organizations, unions, societies, clubs, or centers in Indonesia. CIED provides as many as possible translations for acronyms and initialisms under the above headwords. Under the headword badan, for example. one can find translations of BAPEPAM, BPPT, and BPPN (Stevens \& Schmidgall-Tellings, 2010, p. 72) (vide Figure 1). Under lembaga (vide Figure 2) there are equivalents of $L A N, L B H, L I P I$, and even $L E K R A$, which was famous during the Soekarno's regime, when the Indonesian Communist Party became the ruling party (Stevens \& Schmidgall-Tellings, 2010, p. 572); and under pusat (vide Figure 3) the words available are Puskesmas, Pusdiklat, Pusdikpassus, (Stevens \& Schmidgall-Tellings, 2010, p. 788). In addition, names of political parties, e.g. PDIP, PD, Hanura, $P K S, P K B$, (vide Figure 4) are provided in CIED, including those that may not be present anymore within the 2014 General Election (Stevens \& Schmidgall-Tellings, 2010, pp. 712-713). Certainly, they are very advantageous for translators: presumably they will save much time by consulting one source for the standard and equivalent translations needed (Duval, 2008, p. 274).

....-Pengawas Pasar Modal [BAPÉPAM] Capital
Market Supervisory Agency. - pengelola executive
board. - Pengkajian dan Penerapan Téknologi [BPPT]
Agency for the Assessment and Application of
Technology.-pengurus managing board. - Penyéhatan
Perbankan Nasional [BPPN] Indonesian Bank
Restructuring Agency,...

Figure 1. Some acronyms and initialisms under lemma badan and their translations

... - Bantuan Hukum [LBH] Legal Aid Society. hukuman penal institution. - Ilmu Pengetahuan Indonésia [LIPI] Indonesian Institute of Science. - inang host institution. - Kantor Berita Nasional [LKBN] Antara Antara National News Office. - Kebudayaan Rakyat [LÉKRA] League of People's Culture. ...

Figure 2. Some acronyms and initialisms under lemma lembaga and their translations

... - Keséhatan Masyarakat [Puskésmas] Public Health Center. . . - Pendidikan dan Latihan [Pusdiklat] Training and Educational Center .....-Pendidikan Pasukan Khusus [Pusdikpassus] Special Forces Educational Center . .

Figure 3. Some acronyms under lemma pusat and their translations

... - Amanat Nasional [PAN] National Mandate Party
... - Démokrasi Indonésia Perjuangan [PDIP]
Indonesian Democracy Party Struggle . . - - Démokrat
[PD] Democrat Party . . . - Hanura [Hati Nurani
Rakyat] [PH] People's Conscience Party ... - Keadilan
Sejahtera [PKS] Prosperous Justice Party. -
Kebangkitan Bangsa [PKB] National Awakening Party.
..

Figure 4. Some acronyms and initialisms under lemma partai and their translations 
Another valuable contribution CIED makes is the presentation of many frequently used and found terms in various fields, such as agriculture, biology, economy, engineering, geology, health, language, law, medical, mining, shipping andzoology. That again was beneficial for translators and practitioners looking for the translations of such terms, which they may not find in other Indonesian English dictionaries. See Figure 5 for just some examples of common terms in law under lemma kejaksaan (Stevens \& Schmidgall-Tellings, 2010, p. 403), Figure 6 for some terms in zoology under headword burung (Stevens \& Schmidgall-Tellings, 2010, p. 168), and Figure 7 some terms in shipping under lemma kapal (Stevens \& Schmidgall-Tellings, 2010, p. 447).

kejaksaan 1 prosecution. 2 District Attorney's office. agung [Kejakgung] attorney general's office. negeri [Kejari] district attorney's office. tinggi [Kejati] provincial attorney general's office.

Figure 5. Some common terms in Indonesian law under lemma kejaksaan

...-angin ribut albatross. - angklung chestnut- backed scimitar babbler, Pomatorhinus montanus. - anis mérah orange-headed thrush, Zoothera citrina. - babi adjutant stork, Leptoptilus javanicus. - badak hornbill, Buceros rhinoceros, Dichoceros bicornis. ...

Figure 6. Some terms in zoology under lemma burung

... - angkutan freighter. - api steamship. - api balingbaling propeller ship. - apiso dispatch boat. - asap steamship. - bajak pirate ship. - bantu perambuan buoy watch boat. - bantuan support ship. - barang freighter, cargo vessel. - barang curahan bulk carrier. - . . .

Figure 7. Some terms in shipping under lemma kapal

CIED even covers local and international historical events, such as exemplified in the presentation of a lot of entries under the lemma hari, e.g. hari ABRI, hari Adhyaksa, hari AIDS Sedunia, hari Air Sedunia, hari Anak Nasional, (Stevens \& Schmidgall-Tellings, 2010, pp. 350-353) together with the dates, and peristiwa, e.g. peristiwa Ketapang, Madiun, Semanggi (Stevens \& Schmidgall-Tellings, 2010, p. 741), in which there are brief explanation and dates of the events. However, this lemma needs to be renewed, categories on events should also be established. For instance, do the events only cover the 'dark' side of the country, or both the dark and bright sides.

... - ABRI Republic of Indonesia Armed Forces Day (October 5). - Adhyaksa Attorney General's Oface Day (July 22). - AIDS Sedunia World AIDS Day (December 1). . . . - Anak Nasional [HAN] National Children's Day (July 23) ... - Bhayangkara Police Day
(July 1). - Brigade Mobil [Brimob] Mobile Brigade Day (November 14). - Buku Book Day (May 21). - Bumi Earth Day (April 22). - Buruh Labor Day (May 1) ...

Figure 8. Some terms related to historical events under lemma hari

...- Ketapang interethnic rioting that took place in Ketapang on November 22, 1998. - Madiun The Madiun Affair: September 1948 armed rebellion by the PKI against the government in Madiun, East Java. ... Semanggi demonstrations on November 11, 1998, in Semanggi, Jakarta against the MPR's Sidang Istiméwa [SI]....

Figure 9. Some terms related to historical events under lemma peristiwa

Furthermore, CIED presents examples that are used in Indonesian daily texts as shown in Figure 10 under the headword siapa (Stevens \& Schmidgall-Tellings, 2010, p. 932), which may not be available as comprehensively as in other dictionaries. Note that the various uses of the lexical item siapa as reflected in the examples, have been carefully collected and vividly translated according to the needs of the target users.

siapa who, whom, whose. . . Ini rumah -? Whose house is this? Ada orang datang, saya tidak tahu-. Somebody's coming, I don't know who. - namanya? What's his name? - lagi? (And) who else? - orangnya yang tidak jéngkél? Who wouldn't be annoyed? ngira/nyana ... ? Who would have thought/expected ... ?

Figure 10. Some vivid and useful examples under lemma siapa

Next, teen language or Bahasa Gaul (abbreviated BG) is also highlighted by CIED. Some examples are presented in Figure 11, i.e. ngeh, sléngéan and tulalit (Stevens \& Schmidgall-Tellings, 2010, pp. 332, 414, $948,954,1048)$. I believe they are very useful for those who want to translate the words into English and those non-Indonesian speakers wanting to know about the two varieties.

gubrak (BG onom) crash!
jayus $(B G)$ not funny, stupid (of jokes).
sléngéan and sléngékan ( $B G)$ to do as one
pleases/wants; messy, sloppy; to ad lib.
sotoy $[B G$ sok tahu] a know-it-all.
tulalit $(B G)$ stupid, out of it.

Figure 11. Some lemmata exemplifying teen language in Indonesian

Finally, CIED also includes cultural lexical items from several areas in Indonesia, e.g. Java, Ambon, Sunda, and Minahassa (vide Figure 12). The presence 
of such terms is useful since many of the words, mainly Javanese, have been borrowed and become part of Indonesian vocabulary in written and spoken contexts. The Javenese word ajek, Minahassa ngana, Ambonese nyong, Sundanese punten, for instance, are listed in CIED (Stevens \& Schmidgall-Tellings, 2010, pp. 15, 662, 672, 785). Mostly, it is the Javanese words that have been borrowed and used frequently by Indonesian speakers.

ajeg and ajek (Jv) 1 invariable, constant, steady, stable. 2 regular. dengan - regularly.

ngana (Min) you (personal pronoun sg).

nyong (in Ambon) young man. - dan Noni (Min) (in contests) title awarded to the "best" male and female adolescents from their area.

punten (S) 1 anybody home? 2 excuse me.

Figure 12. Some lemmata from different cultures in Indonesian

\section{THE DEMERITS OF CIED}

In spite of its merits, CIED has its limitations. In the first place, it is concerning the explanation on how to use the dictionary, particularly the order in an entry (Stevens \& Schmidgall-Tellings, 2010, p. xiv). Such an order seems too simple for those who want to have a quick and detailed explanation on how to find equivalents of Indonesian words; many of which are polysemous, and have many derivatives and collocations. Besides, though the dictionary's target users are translators, perhaps not all of them are familiar with linguistic terms. Therefore, it can be practical and helpful to provide illustration and notes as proposed in Figure 13.

The next weakness comes from CIED's inability to keep up with the rapid change of the teen language or Bahasa Gaul. Some of the lemmata may be outdated. One example is astaganaga (Stevens \& SchmidgallTellings, 2010, p. 60), which is not commonly used nowadays. Another example is bo and bo' (Stevens \& Schmidgall-Tellings, 2010, p. 145) which may be outdated, as the lexical item Mr. Bro with the same meaning is currently used by the youngsters. Next example is otreh (Stevens \& Schmidgall-Tellings, 2010 , p. 685), which is not popular today, and replaced by oce or oks. Thus, CIED needs to update old-fashioned words as they have opted for taking Bahasa Gaul into account. Moreover, the extension of cipika cipiki (Stevens \& Schmidgall-Tellings, 2010, p. 204) is not appropriate; it should be cium pipi kanan pipi kiri in which 'pi' is for pipi or cheek (vide Figure 14).

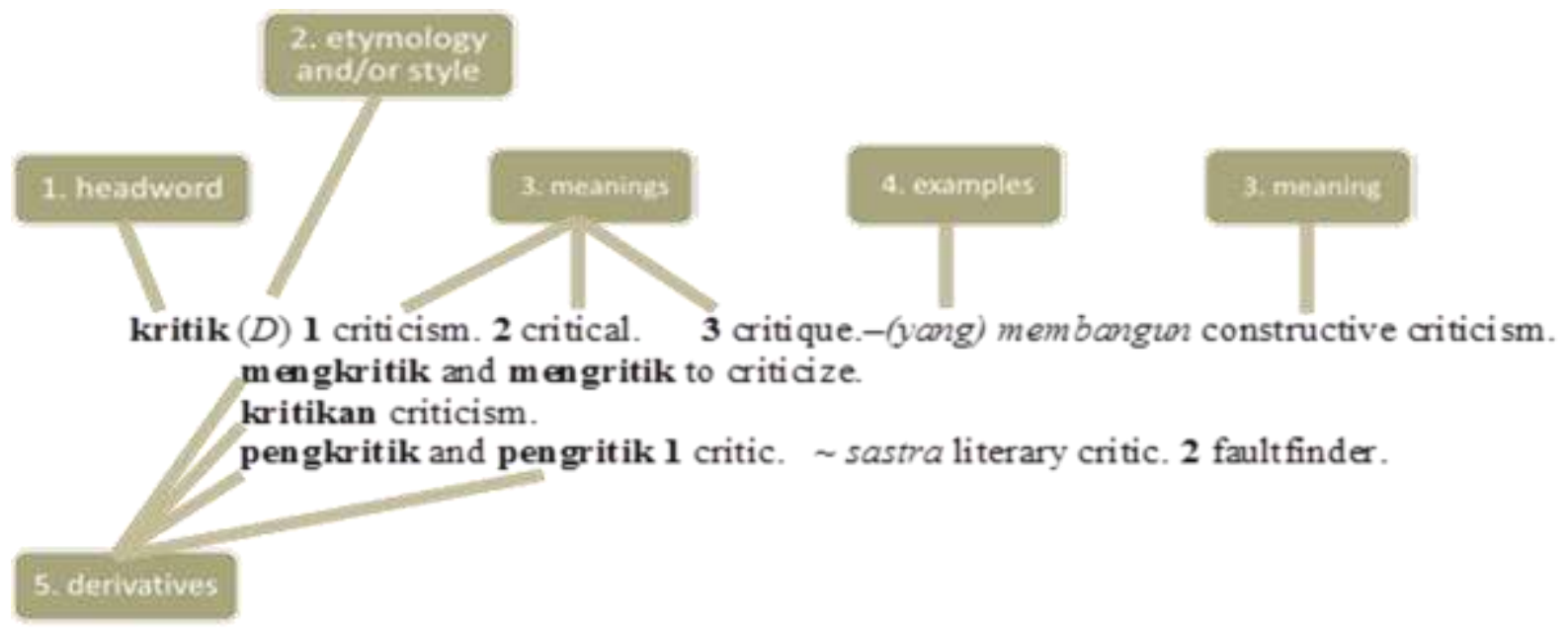

1. headword (usually the root) followed by expansion of an acronym, initialism, or abbreviation (if there is any)

2. etymology and/or style. If no etymology is given, it means that the root is native or that the authors do not know the etymology. A question mark after the etymology means that the etymology is uncertain. Pronunciation comes afterwards if unpredictable from the spelling.

3. meanings. If no meaning is given for the root, the root does not occur by itself or it only occurs as the second element of compounds. The bare root may also be one of the forms of a derivative in $m e N$ - or a colloquial form of a derivative in ber-.

4. examples Notes: idioms, phrases, and sayings (listed under the first full word of the saying) compounds (listed under the first element and alphabetized within each entry under the second element)

5. derivatives and derivatives of derivatives

Figure 13. Proposed order of entry 
cipika-cipiki $(B G)$ [cium kanan cium kiri] (to greet) by kissing on both cheeks.

Figure 14. Lemma cipika-cipiki

Though CIED states that it has a huge collection of real-world examples, some or perhaps many of the examples may not be typical or not frequently used. Factually, examples used in dictionaries should be those that are typical and are indeed commonly employed by speakers of the source language (Rundell, 2008, p. 239). The example és kopyor in Figure 15 below under lemma bagaimana (Stevens \& Schmidgall-Tellings, 2010, p. 73) seems to be atypical of the kind of ice regularly consumed by Indonesians. Typical example would be és teh, és teh manis or es cendol. Another point related to example is the exclusion of one popular example from one lemmata, e.g. kritik pedas that was not included in lemma kritik (Stevens \& Schmidgall-Tellings, 2010, p. 526); (see also Figure 15). CIED needs to count on more updated sources than merely the lengthy experiences of the authors, hence the benefit of using huge corpora of real-use utterances including examples by Indonesians (Laufer, 2008, p. 214).

bagaimana 1 how (about)? . . . - kalau minum és kopyor? What do you think of having a glass of kopyor ice?...

Figure 15. Lemma bagaimana and its atypical example

One more shortcoming of CIED is the multiple definitions it provides for many lemmata (vide Figure 16) (Stevens \& Schmidgall-Tellings, 2010, pp. 447, $756,855)$, which directs to the question of which meaning is the best equivalence. Hence, CIED has to include contexts that match the alternative definitions presented so that users do not have to look up the monolingual English dictionary to ensure his choice is correct. CIED authors may consider establishing and using parallel corpora, which will provide real examples as well as their equivalents in spoken and written texts, which will imply the definitions as well as the contexts (Atkins B. T., 2008, pp. 258, 260).

kapal I (Tam) ship, boat, vessel. ... .

pinjaman 1 (uang ) loan, debt ...

saham $(A) 1$ part, role, share ...

Figure 16. Some lemmata that have more than one meaning

Furthermore, with regard to cultural words, there are some missing points identified. For instance, CIED does not provide a complete definition of a Javanese word blusukan (vide Figure 17). This word has been very popular since Ir. Joko Widodo became the mayor of Solo, Central Java in 2009. The former mayor of Solo, former Governor of Jakarta, and now the President of the Republic of Indonesia (the President) has frequently done blusukan in order to meet people. In CIED the word blusukan is defined only briefly (Stevens \& Schmidgall-Tellings, 2010, p. 145), but the description did not cover the entire meaning. An interview with a Javanese native speaker reveals that blusukan means to go into places that are seldom visited by common people, e.g. slum, forest (Utomo, 2015). Culturally, blusukan may be used to refer to people who go hunting wild boars deep in the forest. However, the word has undergone an extension. When the President does blusukan, he does not just visit places like slums, rural areas, or traditional markets, but also gathers information from the people there by listening to their thoughts, problems, experiences, and having conversations with them. The information is used to evaluate, renew or create a public policy (Widodo, 2015). Hence, blusukan may be also identical with a field observation, a way to monitor people's real condition and how the government's policy has affected people's lives.

blusukan (Jv) to go in and out (of).

Figure 17. Lemma blusukan

On the other hand, CIED has not included the Javanese lexical item mak nyus which was promoted by Bondan Winarno, a host of a culinary program in one of national private TV stations in Indonesia since 2005 (Mayasari, 2012-2015) . The term has always occurred each time Winarno promoted the food he tasted to show how delicious the food is. However, the word has not been included in CIED.

The last note is about acronyms and intialisms Although CIED's convention is to present acronyms as individual words and initialisms as parts of a lemma (Stevens \& Schmidgall-Tellings, 2010, p. xv), CIED should consider putting the many acronyms and initialisms in supplementary materials or outer text accompanying the dictionary for practicality reasons (Szczepaniak, 2007, p. 154). That is due to the fact that there is a plethora of initialisms and acronyms, e.g. those under the lemma badan, lembaga, partai, pusat which are typically used in Indonesian context (Stevens \& Schmidgall-Tellings, 2010, pp. 72, 572, 712, 788). An outer text consisting of those lexical items may help users find the words in question faster and easier. For linguists the way such acronyms and initialisms were translated may provide a clue to whether or not the dictionary makers have a consistent translating work. 


\section{CONCLUSION AND RECOMMENDATION}

So far I have briefly reviewed CIED's current edition from several points of view, i.e. the physical appearance, and the content including the guide for users, local languages, teen language, various terms across fields, cultural words, acronyms, initialisms, and examples. A bilingual dictionary, CIED, can be a one-stop dictionary. It has proved itself to be of a great advantage for its target users (translators), the point that needs to be explicitly stated in the dictionary's preface. CIED, therefore, will not be very appropriate for English learners. Yet, because of the dynamicity of language, CIED needs to renew its content based on the current corpora of both Indonesian speakers and English speakers (cf. Atkins, 2008, pp. 258-271), particularly since CIED has decided to include teen and slang language which change quite fast. Some obvious examples are the currently used lexical items like ciyus (from serius) for serious, cemungud (from semangat) meaning highly motivated, and rempong (from repot) which means busy, which are not available in CIED. Hence, CIED might consider to issue supplementary materials periodically before publishing the next edition to cope with the changes. On the other hand, CIED would consider selecting and omitting some obsolete words or expressions. The provision of etymology of words may also need to be reconsidered because it may not suit the target users' practical needs.

\section{Acknowledgement}

I would like to thank Deny Kwary, Ph.D. for his valuable suggestions and critiques upon the presentation of the first draft of this paper, and Amir Rostamdokht, M.A. for his comment on outer text.

\section{REFERENCES}

Atkins, B. T. (2008). Then and now: Competence and performance in 35 years of lexicography. In T. Fontenelle, Practical lexicography: A reader (pp. 247-272). Oxford: Oxford University Press.

Atkins, B. T., \& Rundell, M. (2008). The Oxford history of English lexicography. Oxford: Oxford University Press.

Atkins, S. (2008). Theoretical lexicography and its relation to dictionary-making. In T. Fontenelle, Practical lexicography: A reader (pp. 31-50). Oxford: Oxford University Press.

Duval, A. (2008). Equivalence in bilingual dictionaries. In T. Fontenelle, Practical lexicography: A reader (pp. 273-282). Oxford: Oxford University Press.
Echols, J. M., \& Shadily, H. (1989). Kamus Indonesia Inggris (3rd ed.). Jakarta: Gramedia Pustaka Utama.

Fontenelle, T. (2008). Introduction. In T. Fontenelle, Practical lexicography: A reader (pp. 1-15). Oxford: Oxford University Press.

Gouws, R. H. (2007). Sublemmata or main lemmata: A critical look at the presentation of some macrostructural elements. In H. Gottlieb, \& J. E. Mogensen, Dictionary visions, research and practice (pp. 55-70). Amsterdam: John Benjamins.

Krause, W. B. (2002). Kamus Indonesia Inggris Trualfa: An Indonesian - English Dictionary Arranged in True Alphabetic Order. Jakarta: Elex Media Komputindo.

Laufer, B. (2008). Corpus-based versus lexicographer examples in comprehension and production of new words. In T. Fontenelle, Practical lexicography: A reader (pp. 213-218). Oxford: Oxford University Press.

Mayasari, E. (2012-2015). Profil berdasarkan abjad: Indonesia: Bondan Haryo Winarno. Retrieved from merdeka.com: http://www.profil.merdeka. com

McEnery, T., \& Wilson, A. (2001). Corpus linguistics: An introduction (2nd ed.). Edinburgh: Edinburgh University Press.

Nielsen, S., \& Mourier, L. (2007). Design of a function-based internet accounting dictionary. In H. Gottlieb, \& J. E. Mogensen, Dictionary visions, research and practice (pp. 119-138). Amsterdam: John Benjamins.

Rundell, M. (2008). Recent trends in English pedagogical lexicography. In T. Fontenelle, Practical lexicography: A reader (pp. 221-245). Oxford: Oxford University Press.

Sneddon, J. (2003). The Indonesian language: Its history and role in modern society. Sydney: UNSW Press.

Stevens, A. M., \& Schmidgall-Tellings, A. E. (2010). Comprehensive Indonesian English dictionary (2nd ed.). Athens: Ohio University Press.

Szczepaniak, R. (2007). Glimpses into receptive dictionary use: Proficient learners' perspective: rationale for the research perspective. In $\mathrm{H}$. Gottlieb, \& J. E. Mogensen, Dictionary visions, research and practice (pp. 147-164). Amserdam: John Benjamins.

Utomo, A. S. (2015, December 4). What is the meaning of 'blusukan". (A. M. da Silva, Interviewer)

Widodo, J. (2015, October 16). Inilah yang harus dilakukan. (B. Tanuredjo, Interviewer) Retrieved from www.kompas.com. 
